\title{
CORRIGENDUM
}

\section{Permanence of molecular features of obesity in subcutaneous adipose tissue of ex-obese subjects}

R Cancello, A Zulian, D Gentilini, M Mencarelli, A Della Barba, M Maffei, P Vitti, C Invitti, A Liuzzi and AM Di Blasio

International Journal of Obesity (2013) 37, 892; doi:10.1038/ijo.2013.44

Correction to: International Journal of Obesity (2013) 37, 867-873; doi:10.1038/ijo.2013.7; published online 12 February 2013

Since the online publication of this article the authors have noticed the following errors.

In Figure 2 , in the $P$-value column, all the + symbols after the $\mathrm{E}$ (of exponential function) should be - symbols. This is important for the statistical relevance of the annotation associations.
In Figure 5b, the $y$-axis '\%D68 + Cells/adipose cell number' should be '\%CD68 + Cells/adipose cell number'.

These errors have now been rectified and the corrected article appears in this issue. The html and online pdf versions have also been amended.

The authors would like to apologize for these errors. 